\title{
The development of Russian Medicine in the Petrine era and the role of Dutch doctors in this process
}

\author{
I. F. Hendriks', J. G. Bovill1, D. A. Zhuravlev², \\ I. V. Gaivoronskii ${ }^{3}$, F. Boer ${ }^{1}$, P. C. W. Hogendoorn ${ }^{1}$ \\ ${ }^{1}$ Leiden University Medical Centre, \\ Postzone H-01-46, PO Box 9600, 2300 RC Leiden, the Netherlands \\ ${ }^{2}$ Military Medical Museum, \\ 2, Lazeretniy per., St. Petersburg, 191180, Russian Federation \\ ${ }^{3}$ Military Medical Academy S. M. Kirov, \\ 6, ul. Akademika Lebedeva, St. Petersburg, 194044, Russian Federation
}

For citation: Hendriks I. F., Bovill J. G., Zhuravlev D. A., Gaivoronskii I. V., Boer F., Hogendoorn P.C. W. The development of Russian Medicine in the Petrine era and the role of Dutch doctors in this process. Vestnik of Saint Petersburg University. Medicine, 2019, vol. 14, issue 1, pp. 158-172. https://doi.org/10.21638/spbu11.2019.208

\begin{abstract}
During the reign of Peter the Great and his successors most significant achievements in the field of public health in Russia took place. In order to train domestic doctors, especially for the army and navy, Peter I organized the training of the best representatives of Russia at the leading medical universities in Europe, and especially at the University of Leiden. He also created the first medical surgical schools in Moscow and St. Petersburg. In the seventeenth and eighteenth centuries, close ties in the field of medicine between Russia and the Netherlands were established. A significant number of doctors, graduates of the Leiden University practiced in Russia and held very high positions in Russian medical services. This contributed to the advancement of advanced European technologies in the provision of medical services and medical education in Russia. Therefore the role of Dutch doctors in the development of Russian medicine in the Petrine era is extremely significant. Under their leadership, the first hospitals and medical schools were established, the first textbooks were developed in Russian and scientific research was conducted. The Academy of Sciences created by Peter the Great was the centre of scientific achievements of Imperial Russia.
\end{abstract}

Keywords: history, medicine, Peter the Great, Bidloo, Boerhaave, Holland, pre-1917 Russia.

\section{Introduction of Peter the Great to Holland}

Peter the Great in 1682 became the Tsar of Russia at a very young age of ten years. Simultaneously, Ivan Alekseevich ${ }^{1}$, his handicapped half-brother brother claimed the throne. This double rule lasted until the death of Ivan Alekseevich in 1696 [1-4].

The young rulers sent a letter in Latin to the German Emperor Leopold with the request to find two suitable experienced doctors who could take care of their health. Two years later, Gregorius Carbonarius von Bisenegg of Austrian roots and Jakob Pelarino of Greek roots arrived in Russia [2; 5].

In childhood, Peter the Great had many friends both among Russians and foreigners. One of his closest friends was the family doctor Johan Termont, an experienced Dutch barber-surgeon. He was the first teacher of Peter in theoretical and practical medicine $[3 ; 6]$.

\footnotetext{
${ }^{1}$ We have used common English transcription for the Russian names.

(C) Санкт-Петербургский государственный университет, 2019
} 
In 1697, after the death of his brother Ivan, Peter made his first visit to Europe with the Grand Embassy (a diplomatic mission to strengthen the union of Russia with a number of European countries). He repeated the same visit in 1716-1717. His childhood friends and his travels abroad influenced Peter's views on the modernisation of Russia $[1 ; 7]$.

In the seventeenth century, the centre of the world's anatomical studies moved from Italy ${ }^{2}$ to France, England and particularly to the Netherlands (Holland), since a papal decree excluded all non-Catholics from Italian universities. As a result of these reforms, the University of Leiden, founded in 1575 by Stadtholder Willem the Silent, became a heaven for all students, regardless of race, nationality or religion, and became famous for its anatomical and medical school [8-10]. In October 1698, Tsar Peter I visited by carriage the Leiden University and anatomical theatre. He was very interested in the history of the establishment and laws of this university, and Professor Govert Bidloo, the university's director and president of the board of directors (Rector Magnificus), presented him with a Latin general description of everything concerning the university [11-13].

On 17 March 1717 Peter the Great, now by yacht, again visited Leiden and its university. The city welcomed him with cannon firing. He stayed two days in Leiden. Peter I was received by Rector Magnificus Herman Boerhaave and the collective of professors. He again recorded the establishment of the university and the curriculum, examined the library and all sorts of mathematical and mechanical machines and tools. When leaving the university, Peter was told about the history and didactic presentations. After that, he inspected all the factories and manufactories in Leiden and talked in detail with the masters [14].

Tsar Peter met with Herman Boerhaave, but it was Tsarina Anna Ivanovna (17301740), who invited him to become Arkhiyater. In a letter to his former student, Laurentius Blumentrost dated 1730, Boerhaave officially thanked for the invitation, but declined the position [15].

In Amsterdam, Peter visited the anatomical theatre and listened to lectures by Ruijsch and even participated in autopsies. Frederik Ruijsch (1638-1731) was a Leiden graduate, who became professor of anatomy to the guild of surgeons of Amsterdam and chief-instructor of midwives $[7 ; 10 ; 16 ; 17]$. He had accumulated a unique and well-known collection of anatomical preparations. Ruijsch worked with Jan Swammerdam, another medical graduate from Leiden, who also made an important contribution to the study of anatomy. Swammerdam injected a coloured liquid wax into the blood vessels to study blood circulation, and Ruijsch proposed using a microscope designed by Antoni van Leewenhoek to inject the wax into the smallest blood vessels. Frederik Ruijsch gave anatomy lessons to Peter I, during which he told how to examine patients, prescribe medications and conduct operations. While in the house of Ruijsch, Peter I admired a large collection of anatomical specimens and Ruysch presented the Tsar 25 of his exhibits [6;12].

Further, the Tsar visited the city of Delft. During this visit to Anthony van Leeuwenhoek, he was fascinated by the way the microscope allowed him to "see such tiny objects", and he took one of the microscopes with him to Russia (Fig.1). Peter had an above average interest in surgery. He was able to perform autopsies, make surgical incisions, perform phlebotomy, suture wounds and extract teeth (Fig. 2). After Peter I's first visit to Europe in 1699, he held several lectures in Moscow for the boyars (noble men) on anatomy, with demonstrations on corpses.

\footnotetext{
${ }^{2}$ We have chosen for today's names of countries to make it less complicated for the reader.
} 

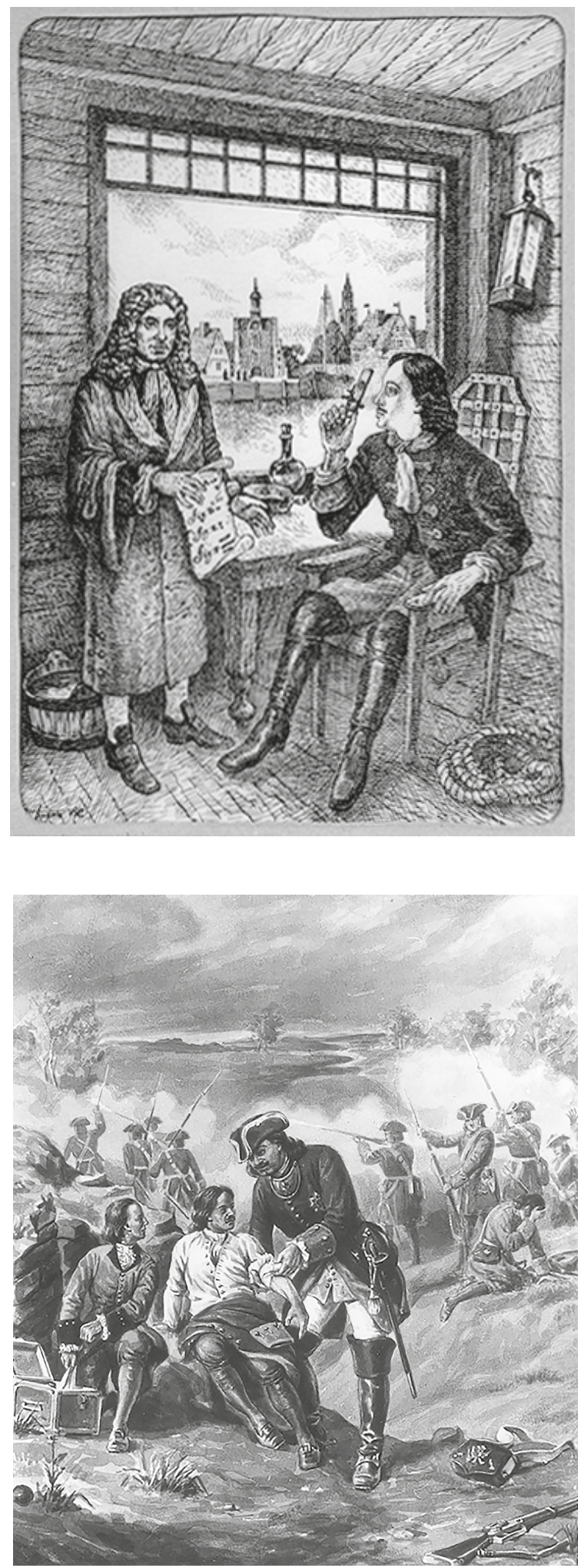

Fig. 1. Peter I and Antoni van Leeuwenhoek in the city Delft, pen-and-ink drawing, artist V.S.Bedin, 2004, Image OF-87224. Military Medical Museum of Defence Ministry of Russian Federation, St. Petersburg. Reproduced with their permission
Fig. 2. Peter I provides medical care in Azov 1696, watercolour, artist V.I. Peredery, 1950, Image OF-35880. Military Medical Museum of Defence Ministry of Russian Federation, St. Petersburg. Reproduced with their permission 


\section{The first domestic doctors}

What the Tsar learned and observed during his European tour, had a significant impact on the development of modern Medicine in Russia. It should be noted that his reign significantly changed the Russian economy, which contributed to the development of medicine and improved education $[1 ; 7 ; 18]$. The Tsar was well aware of the need to train medical personnel for the Russian army and navy, as in Russia there was an acute shortage of domestic doctors of medicine and barber-surgeons, most needed in the army and navy, which were serviced almost exclusively by foreign doctors.

Peter had two solutions for this problem: send Russians abroad for higher education and/or establish medical schools in Russia. Both solutions ran in parallel until the third quarter of the eighteenth century. Several foreign doctors from the Netherlands, Germany and France were recruited $[1 ; 2 ; 6]$. One of them was the Scot John Brock, a graduate of Cambridge University, who also studied in Holland. The personal physician of the imperial family since 1668, Laurentius Alferov Blumentrost Sr. considered Brock an empirical doctor, not a doctor of medicine (Doctor Medicinae), because he could not speak Latin, which at that time was the language of teaching in European and British universities. Nevertheless, given the extensive medical experience of Brock, he was accepted in the Aptekarskiy Prikaz ${ }^{3}$, provided he kept a diary of his patients.

Peter the Great also sent Russian students to the universities of Padua, Göttingen, Haller and, most importantly, Leiden (Holland). In the seventeenth and eighteenth centuries, Russia and Holland had close relations in the field of medicine and many Dutch doctors were invited to Russia for practical activities and the organisation of medical education. $[1 ; 4 ; 19]$. The first two Russians sent abroad to study Medicine on a scholarship were Pyotr Vasilievich Posnikov and Johann (Ivan) Deodatus Blumentrost. Both returned doctors of Medicine and Philosophy.

Pyotr Vasilievich Posnikov (1676-1716), a student of the Moscow Slavic-Greek-Latin Academy, was the first to benefit from the decision for many promising young Russians to undergo education abroad at the expense of the state $[1 ; 20 ; 21]$. In 1692, he was sent to study medicine at the Padua University, where after two years of training he was awarded a Doctorate in Medicine and Philosophy. He then further developed his medical expertise in Venice, Paris, Brussels and Leiden. In Leiden, he attended the clinics of Hermann Boerhaave and studied with the famous Dutch anatomist Frederik Ruijsch. Although he became the first Russian doctor who entered the Apthekarskiy Prikaz, he never practiced medicine. Since he mastered several languages Peter Posnikov spent most of his time as an interpreter in the service of the Tsar. He died in 1716 at the age of 43 years.

The second Russian, who was also sent abroad, was Johann Deodathus Blumentrost (1692-1756), the third son of the old court physician Laurentius Alferov Blumentrost. After studying in Germany and France, he completed his medical studies in Leiden in 1713. Later J. D. Blumentrost succeeded Robert Erskine as Arkhiyater of the Aptekarskaya Kantselyariya ${ }^{4}(1719-1731)$, the supreme body for management of medical affairs in Russia $[1 ; 7 ; 19 ; 20]$.

${ }^{3}$ Historical meaning for "Приказ" is "Ministry" according to the explanatory dictionaries of the Russian language of S. I. Ozhegov and N. Yu. Chvedova and of V. Dal'.

${ }^{4}$ Historical meaning for "Канцелярия" is "Chancellery" according to the explanatory dictionaries of the Russian language of S. I. Ozhegov and N. Yu. Chvedova and of V. Dal.' 


\section{The establishment of the first hospital with a medical school and anatomical theatre in Russia}

Sending young Russians abroad to be educated in Medicine did not solve the problem of the shortage of domestic doctors. Until the time of Peter the Great, there was not a single classical scientific medical school in Russia, only a school of barber-surgeons for the army and navy, which was opened by the Aptekarskiy Prikaz in 1654 [1;6;22;23]. The first anatomical book, used in this school, was "Epitome, Amsterdam, 1642" by Andreas Vesalius. It was translated in 1658 by the monk Epiphany Slavinetsky and was named "Vrachevskaya Anatomy" [7].

The development of medical education along the European lines was largely carried out by foreign doctors, in particular, by doctors from the Netherlands. At the beginning of the eighteenth century, the University of Leiden (the Netherlands) was in Europe at the forefront in the development and implementation of the clinical method, mainly due to one person, Hermann Boerhaave (1668-1738), who was a convinced follower of Hippocrates and Thomas Sydenham. The latter believed that the disease should be studied and observed in a systematic and accurate manner [24]. In 1701, Boerhaave was appointed as a lecturer and coverer to replace Govert Bidloo, professor of anatomy, medicine and practical medicine, during his absence as personal physician of the King-Stadtholder William III [13]. In 1709, Boerhaave became professor of Medicine and Botany, and in 1718 also professor of Chemistry [24]. Boerhaave emphasised the importance of observing the patient directly at the bed, combining a thorough physical examination with a physiological and anatomically rational diagnosis. These methods were previously introduced in Leiden by Johannes van Heurnius, (1543-1672) and Franciscus de le Boe Sylvius (1614-1672) [25-27]. The lectures by H. Boerhaave attracted not only such students as A. Haller and G.Van Swieten, but also Russians who played a significant role in Russian health care. Among such pupils in 1717 was Tsar Peter the Great during his second visit to Leiden [28; 29]. During the eighteenth century, about 46 native Russians and Russians with foreign roots studied in Leiden. Of this number, $25 \%$ (12 people) studied at the time of Herman Boerhaave (Appendix).

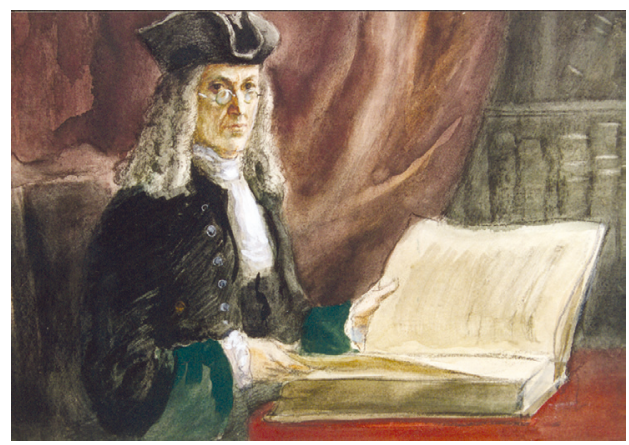

Fig. 3. Nicolaas Bidloo standing at the table with a book, watercolour, artists of Lenfront Masterskie VSULF, December 1943, Image OF 7787. Military Medical Museum of Defence Ministry of Russian Federation, St. Petersburg. Reproduced with their permission
After taking the throne, Peter the Great began to look for another court physician and invited Nicolaas Lambertus Bidloo (1673/4-1735) for this position (Fig. 3). He accepted Peter's offer in 1702 and became the personal court physician of His Imperial Majesty in 1703. Before moving to Russia, he already had a successful medical practice in Amsterdam $[1 ; 30]$. He successfully completed and defended his thesis at the University of Leiden in 1696. His father Lambert Bidloo, the brother of Govert Bidloo, was a pharmacist in Amsterdam. One of his teachers was Carol Drelincourt (1633-1697), who was also the mentor of Hermann Boerhaave. As 
already noted, Govert Bidloo since 1694 was a professor of anatomy, medicine and practical medicine, and since 1696 also Rector Magnificus of Leiden University. In addition, Govert Bidloo was the personal court physician of Willem III, the Dutch Stadtholder and King of England, who in 1691 appointed him head of all civil and military doctors, pharmacists, surgeons and hospitals in the Netherlands and England. Peter the Great became friends with the Stadtholder and visited him in the Netherlands, as well as in England. Nicolaas had been recommended by his uncle Govert Bidloo as the court physician to the Tsar $[31 ; 32]$.

As the personal physician of the Tsar N. Bidloo had to accompany Peter I on campaigns and travels in Russia and on his trips to Europe. However, Peter the Great was a healthy man and Bidloo had little to occupy him in a professional capacity. After some time he became dissatisfied with his functions and asked the Tsar to release him from the duties as a personal physician "...due to my indisposition and weakness..." [1;22; $30 ; 33]$. This was an excuse, because, based on his workload, there was little evidence of "indisposition and weakness." Peter I agreed to his request and ordered him by a decree of 1706 to build near the German settlement on the banks of the Yauza River in Moscow a medical hospital school to teach the students anatomy and surgery [34]. Bidloo was not only a well-known physician, but also a talented architect. He himself drew up the plans for a medical school, a hospital, a botanical garden and an anatomical theatre, where the Tsar later regularly attended dissections $[1 ; 20 ; 33 ; 35 ; 36]$.

The medical hospital school was officially opened on 21 November 1707 by Peter the Great himself.

The curriculum at the hospital school included anatomy conducted on corpses in the anatomical theatre, surgery, internal medicine, autopsy, chemistry, drawing and Latin. Pharmacy was studied in the botanical garden. The hospital complex was the first for modern education in Russia.

Bidloo became director of the hospital, professor of anatomy and surgery at school and head of the anatomical theatre. In these positions he remained until his death on 23 March 1735.

It should be noted that there were in the first Medical Hospital School no textbooks, and Bidloo taught students by using his handwritten books in Latin, such as "Speculum anatomiae" [Mirror of Anatomy]; "Praelectoris thesaurus medico-practicus" [Treasury of medical and practical lectures]; "Instructio de chirurgia in theatro anatomico studiosis proposita" [Surgical training in the anatomical theatre for students]. Only in 1967 the latter was for the first time translated into Russian and published [23].

In the study of anatomy, Bidloo also used the book of Govert Bidloo "Anatomia humani corporis, 1687" [Anatomy of the human body], which was translated specifically for Peter the Great, and also the atlas "Outleding des menschliken Lichaams, Amsterdam, 1690" [Dissection of the human body]. The students of the first medical hospital school in Russia were graduates of the Slavic-Greek-Latin Academy of the Holy Synod. They were by origin Russian and foreigners from all strata of the population. Their education was paid by the state [1;7] (Fig.4).

After the death of Nicolaas Bidloo, Antonius de Theyls, a Russian with Dutch roots, became his successor. He also studied at Leiden University $[1 ; 19 ; 20]$.

The budget for the construction of the hospital complex and the medical school, the purchase of medicines, the salaries of doctors, barber-surgeons and students came from 


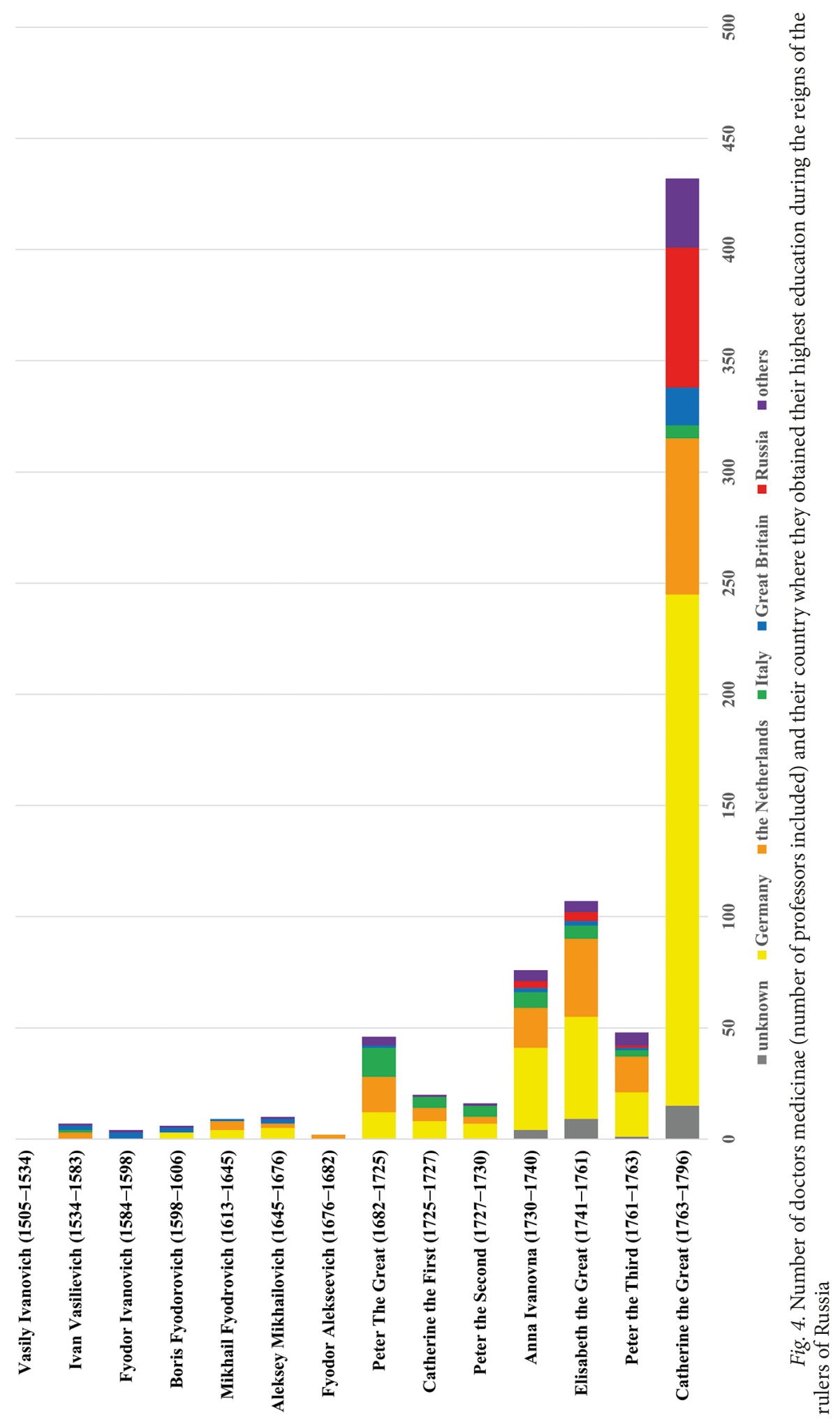


the Holy Synod of the Orthodox Church and was calculated on the basis of the percentage of weekly collections accepted in the church service. This form was specifically organized so N. Bidloo could manage independently of the Aptekarskaya Kantselyariya. The daughter of Tsar Peter the Great and Tsarina, Elizabeth the Great (1741-1762), continued this arrangement, but also introduced a law according to which from the wages of civil servants, from each earned rouble 1 kopeck ( 1 rouble $=100$ kopecks) was withheld to maintain hospitals and care for the sick [1].

For almost 70 years, the first medical hospital school has trained many barber surgeons for the army and navy and trained talented graduates for a $\mathrm{PhD}$ degree in Medicine abroad.

Peter the Great paid special attention to the armed forces. According to his decrees, hospitals were built for the army and navy in Moscow and St. Petersburg 5 [1;6]. In 1715 in St. Petersburg was founded the second ground force hospital (military hospital) and the navy hospital (Kronstadt hospital) along the lines of the medical hospital school in Moscow. In 1716, the Tsar personally wrote military rules in Russian and Dutch, in which are indicated the number of doctors, surgeons and pharmacists needed for the army [2; 37]. According to these rules, in each division should be an academically qualified doctor of medicine and a podlekar (staff surgeon); in each regiment a lekar (surgeon); in each company a feldsher/paramedic (barber-surgeon/phlebotomist). For the army two military pharmacies were established, one for the infantry and one for the cavalry. Each should be staffed by one pharmacist, two assistants and four trainees. The students of the medical school were sent mainly to the regiments, where after a certain period of practical work, they received the title of assistant surgeon or barber-surgeon $[1 ; 2 ; 7 ; 18]$.

In an effort to increase the number of medical students Tsarina Elizabeth the Great (1741-1761) in 1748 instructed the church schools in Moscow to send more pupils to the medical schools [7]. The teaching in the schools was expanded. Mostly surgical subjects were taught, the curriculum was revised, textbooks were developed and specially written in Russian.

The first ethnic Russian to be appointed chief physician of the Moscow hospital, was Muscovite Martin Ivanovich Shein (1712-1762) $[1 ; 19 ; 20]$. He graduated from the Moscow Medical Hospital School and taught surgery in the hospital school. Another ethnic Russian, Konstantin Shchepin (1728-1770), also a graduate of the Moscow Medical Hospital School, received his $\mathrm{PhD}$-degree in Leiden, and became in 1762 the first Russian director of the medical hospital in Moscow.

Russia's first hospital and medical school in Moscow, managed by N. Bidloo, was originally civilian. In 1757, the Medical Hospital School was renamed the "First Groundforce Hospital in Moscow" (now the Main Military Clinical Hospital named NN Burdenko) [7]. In 1786, both military medical hospital schools (in Moscow and St. Petersburg, the medico-surgical schools) were separated from the hospitals and converted into independent medical schools. They received the right to award their students a doctorate in medicine. Before that, it was the exclusive right of the Meditsinskaya Kantselyariya. In 1798, 12 years later, the Medico-surgical Schools were renamed Medico-surgical Academies. The Moscow Medico-surgical Academy existed until 1804, when its 45 students, all medical in-

\footnotetext{
${ }^{5}$ From 1703 till 1917 St. Petersburg was the capital of Imperial Russia.
} 
struments, anatomical preparations and a library were transferred to the Medico-surgical Academy in St. Petersburg.

\section{The Kunstkamera, first museum of anthropology and ethnography in Russia}

In 1716-1717, Peter the Great again went to Europe, visiting France, the Netherlands and other countries. In Amsterdam he once again visited Frederik Ruijsch, but this time he was more interested in purchasing the anatomical collection of Frederik Ruijsch for the Kunstkamera in St. Petersburg [7; 16; 38]. As a result, an agreement was reached on the sum of 30.000 guilders [14]. This is a huge amount by the standards of the eighteenth century. Peter the Great also succeeded in literally "worming out of" Ruijsch's secrets for embalming his exhibits. The Tsar passed this knowledge to his personal physician Johann D. Blumentrost, who was appointed as the chief supervisor in obtaining the collection, preparing it for the transfer to Russia, maintaining it in a proper condition.

Blumentrost in turn passed on the secret to his successor as Arkhiyater, the Dutchman Johan Ch. Rieger, who finally wrote down the secret of embalming and made a secret publication. The Ruysch collection was placed in the first Russian museum of the former Academy of Sciences (now known as the Kunstkamera, Museum of Anthropology and Ethnography) in St. Petersburg. By order of Peter I, beginning in February 1718, the Kunstkamera acquired all examples of malformations both of humans and animals in Russia. The Tsar also bought in 1716 the collection of the natural history of the apothecary Albert Seba. In 1721 a complete medical library and a rich collection of other rare items such as minerals and shells, owned by Peter's court physician Robert Erskine were added to the Kunstkamera $[1 ; 7 ; 16]$.

\section{The Academy of Sciences as the centre of the development of science in Imperial Russia}

University education in Russia dates back to 1724, when Peter the Great established the Academy of Sciences in St. Petersburg along the lines of the French Academy, which he had visited in 1717 . His idea was for the Academy to function both as a scientific and educational institution. He donated his personal library and the Kunstkamera to the newly created Academy of Sciences. For the maintenance of the Academy, Peter I identified each year a share of the customs revenues from among others Dorpat and Narva. Unfortunately, Peter I could not see his creation, since he died in February 1725, before the Academy of Sciences was opened in 1726. After the death of Peter I, his widow, Catherine the First (1725-1727), continued her husband's work. The first meeting of the Academy took place on 27 December 1725 in the presence of the Tsarina, and its grand opening took place on 1 August 1726.

The Academy established a grammar school and a university with three faculties (medicine, philosophy and law). In 1726 in the first school in St. Petersburg was opened a grammar school, at the beginning of the year it received 120 students, but in the second year 58 [1; 7; 18]. Students from religious institutions came to the university. These students were awarded grants-aided, they knew Latin in which the education was given. The university contained a library, an astronomical observatory, an anatomical theatre and a botanical garden. 


\section{Dutch members of the Imperial Academy of Sciences}

The first president of the Academy of Sciences was the court physician of the Tsar Peter, Laurentius Lavrentovich Blumentrost (1692-1755), the youngest son of Blumentrost the eldest. Like his brothers, he also graduated from the University of Leiden $[1 ; 2 ; 20$; 39]. In 1726 and 1727, several experienced doctors arrived in Russia, who were admitted to the Academy. Among them was the elder brother of the president Johannes Deodatus Blumentrost, general director of Meditsinskaya Kantselyaria, and Michael Burger, both alumni of the University of Leiden. In 1744, the youngest of the two brothers Kaau-Boerhaave Abraham became also a member of the Imperial Academy of Sciences in St. Petersburg, when he was still a practicing physician in The Hague (Holland). Abraham came to St. Petersburg in 1746, where he first received a position in the Admiralty Hospital. In 1748 he succeeded Josias Weibrecht, he worked as a professor of anatomy and physiology and left eight scientific manuscripts in Latin [1].

An interesting incident occurred in the life of Abraham Kaau-Boerhaave. One night in 1736, Abraham suddenly became deaf and could express himself only with the help of sign language or by writing. Despite this shortcoming, he was able to defend his thesis in perfectly written Latin. In 1738, he graduated from Leiden University as a doctor of medicine. The curators of Leiden University were so surprised at this feat that in his honour a special gold medal was instituted. Abraham died in 1758 in Russia, and with him died the surname Boerhaave.

Also worth mentioning is Alexis Protassiev, who first studied medicine in Leiden, and afterwards anatomy at the Imperial Academy of Sciences, where his teacher and mentor was Abraham Kaau-Boerhaave. Protassiev was one of the first native Russians, who specialised in this subject. He was appointed professor of anatomy at the Academy of Sciences $[1 ; 4 ; 31]$.

Barber-surgeon Johan Friedrich Mautt, born in St. Petersburg, was appointed the assistant and translator for Herman Kaau-Boerhaave in the Imperial Academy of Sciences. Mautt went on to study medicine in Leiden and graduated as a doctor medicine and philosophy in $1760[1 ; 20]$.

Other Dutch members of the Imperial Academy of Sciences were father and son De Gorter. Father Johannes de Gorter studied medicine in Leiden. Under the chairmanship of Bernhard Siegfried Albinus (1697-1770), professor of anatomy and Rector Magnificus of Leiden University, he discussed various physiological and pathological theories. In 1725 Johannes de Gorter became a city physician and professor of medicine at the University of Harderwijk. His son David, a student of the Leiden University, became a professor of medicine and botany in Harderwijk. They both agreed to become the second and third court physicians of Tsarina Elizabeth and also were elected a member of the Academy of Sciences. After the death of his wife in 1758, Johannes returned to the Netherlands. He left in Russia 23 scientific manuscripts $[1 ; 20]$.

Another member of the Academy was the scientist Karl Friedrich Kruse, who also studied medicine at the Leiden University. For a long time he served as the chief physician of the Imperial Lifeguards in St. Petersburg. During the reign of Catherine the Great, he was appointed assistant of the personal physician of the Tsarina and the State Councillor (in 1770). His wife was the daughter of Herman Kaau-Boerhaave. During the eighteenth century, other well-known Dutch professors from Leiden were invited to Russia, but they 
did not always accept the offered positions. Among them are Bernard Siegfried Albinus and Hieronymus Davides Gaubius [40; 41].

\section{Conclusion}

During the reign of Peter the Great and his successors, the most significant achievements in the field of public health in Russia took place. In order to train domestic doctors, especially for the army and navy, Peter I organised education for the best representatives of Russia in the leading medical universities in Europe, and especially at the University of Leiden, and also created the first medico-surgical schools in Moscow and St. Petersburg. In the seventeenth and eighteenth centuries, close ties in the field of medicine between Russia and the Netherlands were established. A significant number of doctors attending the University of Leiden practiced in Russia and held very high positions in Russian medical services. The Academy of Sciences created by Peter the Great was the centre of scientific achievements of Imperial Russia.

\section{Acknowledgements}

The authors are grateful for the tremendous assistance and support they received from the President of the Anatoly Sobchak Foundation, Mrs. Lyudmila B. Narusova, for access to the archives of museums and libraries in St. Petersburg. They are also grateful to the staff of the Military Medical Museum and the Military Medical Academy named C. M. Kirov in St. Petersburg for their help and enthusiasm.

We would like to express special gratitude for the help of the late Mr. Anton Nikolayevich Gubankov, the former head of the culture department of the Ministry of Defence of the Russian Federation. Unfortunately, Anton was killed in a plane crash on 25 December 2016. Without his help and support, our task of researching the material would be much more complicated. He will be missed.

\section{References}

1. Richter W.M. Geschichte der Medicin in Rusland. Dritter Theil, 1 edn. Moscow, N.S. Wsewolojsky Publ., 1817.

2. Richter W.M. Geschichte der Medicin in Rusland. Zweiter Theil, 1 edn. Moscow, N.S. Wsewolojsky Publ., 1815.

3. Van Esso I. Hollandsche artsen in Russischen Hof- en Staatsdienst in de 16e, 17e en 18e Eeuw. Ned. Tijdschr. Geneeskd, 1938, no. 82, vol. I, pp. 1102-1112.

4. Hans N. Russian Students at Leyden in the $18^{\text {th }}$ Century. The Slavonic and East European Review, 1957, no. 35 , pp. 551-562.

5. Dumschat S. Ausländische Mediziner im Moskauer Rußland. Munich, Franz Steiner Verlag GmbH, 2006.

6. Samoylov V. O. History of Russian Medicine. Moscow, Epidavr Publ., 1997. (In Russian)

7. Sorokina T.S. History of Medicine. Moscow, Academia Publ., 2008. (In Russian)

8. Lyons A. S., Petrucelli R. J. Medicine. An Illustrated History. New York, US, Harry N. Abrams Inc., 1987.

9. Guthrie D. The influence of the Leyden school upon Scottish medicine. Med. Hist., 1959, no. 3, pp. 108-122.

10. Huisman T. The Finger of God. Anatomical Practice in $17^{\text {th }}$-Century Leiden. Leiden, Ptimavera Pers, 2009.

11. Golikov I. I. Supplement to the acts of Peter the Great. Volume IV. Containing an addition to Volume I about these acts. Moscow, University printing press of V. Okorokov, 1790. (In Russian) 
12. Golikov I. I. Acts of Peter the Great, wise transformer of Russia, Collection of reliable sources and locations per year. Part I. Moscow, University printing press of V. Okorokov, 1788. (In Russian)

13. Bidloo Govart (Govert). Leiden Medical Professors 1575-1940. Leiden, Boerhaave Museum - Leids Universitair Medisch Centrum, 2007, pp. 78-80.

14. Golikov I. I. Acts of Peter the Great, wise transformer of Russia; Collection of reliable sources and location per year. Part V. Moscow, University printing press of V. Okopokov, 1788. (In Russian)

15. Boerhaave H. Brief aan Laurentius Blumentrost, 13 June 1730. St. Petersburg, Fundamental Library of the Military-Medical Academy. In: Ed. Ep. XIII-89, pp. 74-75.

16. Ipma F. F. A. The Anatomy Lessons of the Amsterdam Guild of Surgeons. Enschede, Gildeprint, 2016.

17. Boer L., Radziun A.B., Oostra R.J. Frederik Ruysch (1638-1731): Historical perspective and contemporary analysis of his teratological legacy. Am. J.Med Genet., 2017, January, no. 173 (1), pp. 16-41.

18. Garrison F.H. Russian Medicine under the Old Regime. Bull. N.Y. Acad. Med., 1931, no. 7, pp. 693734.

19. Van Esso I. Vreemde artsen in Russischen staatsdienst, in Holland gestudeerd hebbende. Ned. Tijdschr. Geneeskd, 1938, no. 82, vol. IV, pp. 5399-5410.

20. Chistovich Y. History. The first medical school in Russia. St. Petersburg, Yakova Treya, 1883. (In Russian)

21. Steiman I. P. V. Posnikov: Pioneer Russian Physician. Can. Med Assoc. J, 1965, no. 92, pp. 615-618.

22. Oborin N.A. The first Centre for Higher Medical Education in Russia. (For the $280^{\text {th }}$ anniversary of the Moscow hospital and the Moscow medical-surgical school - the Military Medical Academy named after S. M. Kirov). Klin Med (Mosk), 1990, no. 68, pp. 118-121. (In Russian)

23. Bidloo N. L. Textbook for students of surgery in the anatomical theatre. Translated from Latin to Russian language by M. V.Danilenko in 1979. Moscow, Meditsina Publ., 1710. (In Russian)

24. Boerhaave Herman (Hermannus). Leiden Medical Professors 1575-1940. Leiden, Museum Boerhaave/ LUMC Leids Universitair Medisch Centrum, 2007, pp. 85-88.

25. Heurnius Johannes (Van Heurne). Leiden Medical Professors 1575-1940. Leiden, Museum Boerhaave/ LUMC Leids Universitair Medisch Centrum, 2007, pp. 22-24.

26. Boe Sylvius Franciscus de le (Delaboe Sylvius, Dele Boe Sylvius). Leiden Medical Professors 1575-1940. Leiden, Museum Boerhaave/LUMC Leids Universitair Medisch centrum, 2007, pp. 54-57.

27. Ragland E. V. Experimental Clinical Medicine and Drug Action in Mid-Seveteenth-Century Leiden. Bull. Hist. Med. 2017, pp. 331-361.

28. Scheltema J. Peter de Groote, keizer van Rusland, in Holland en te Zaandam in 1697 en 1717. Eerste Deel. Met platen. Amsterdam, Hendrik Gartman, 1814.

29. Lindeboom G. A. Boerhaave and his time. Papers read at the international symposium in commemoration of the tercentenary of Boerhaave's birth Leinde, 15-16 November 1968. Leiden, E. J. Brill, 1970.

30. Willemse D. Nicholas Bidloo and his unknown drawings. Janus, 1976, no. 63, pp. 195-206.

31. Lindeboom G. A. Herman Boerhaave the man and his work. $2^{\text {nd }}$ ed. Rotterdam, Erasmus Publishing, 2007.

32. Haneveld G.T., Fokke H.E. Geneesheer en Hoogvoorlezer in de Ontleding- en Heelkunst Govert Bidloo (1649-1713) en Koning-stadhouder Willem III. In: Van Everdingen J.J.E., Meulenberg F., Fokke H. E. and Six A. J., eds. Op het lijf geschreven. Bekendheden en hun lijfarts. Amsterdam/Overveen, Boom/Belvedere, 1995, pp. 95-103.

33. Abashin V.G., Tsvelev I. Doctor Medicinae Nikolaas Bidloo, serving Russia. St. Petersburg, Voennomeditsinskaya akademiya im. S. M. Kirova Publ., 2009. (In Russian)

34. Golikov I. I. Acts of Peter the Great, wise transformer of Russia; Collection of reliable sources and locations per year. Part II. Moscow, University printing press of V. Okorokov, 1788. (In Russian)

35. Hamstra E. W. F., Six A. J. Bouwheer van de Tsaar Nicolaas Bidloo (1674-1735) en Peter de Grote. In: Van Everdingen J. J. E., Meulenberg F., Fokke H. E. and Six A. J., eds. Op het lijf geschreven. Bekendheden en hun lijfarts. Amsterdam/Overveen: Boom/Belvedere, 1995, pp. 104-113.

36. Romaniuk V.P. N. L. Bidloo - the first teacher of surgery in Russia. Voen Med Zh, 1993, pp. 69-70. (In Russian)

37. Romanov P. A. Charter of the Marine. St. Petersburg, 1724. (In Dutch and Russian)

38. Kopaneva N. P., Kistemaker R., Overbeek A. Peter I and Holland. Saint Petersburg, Evropeyskiy Dom, 1997. (In Russian)

39. Richter W. M. Geschichte der Medicin in Rusland. Erster Theil. 1 edn. Moscow, N. S. Wsewolojsky Publ., 1813.

40. Albinus A.S. Letter to A. Kaau-Boerhaave, 30 October 1754. St. Petersburg, Fundamental Library of the Military Medical Academy Publ. In: Ed. Ep. XIII-88, p. 20. 
41. Gaubius H. A. Letter to A. Kaau-Boerhaave, February 1755. St. Petersburg, Fundamental Library of the Military Medical Academy Publ. In: Ed. Ep. XIII-88, pp. 17-18.

Authors' information:

Inge F. Hendriks - MA; ifhendriks@lumc.nl

James G. Bovill — MD, PhD, FCAOI, FRCA; jgbovill@gmail.com

Dmitrii A.Zhuravlev - MA, PhD; demetrio_s@mail.ru

Ivan V.Gaivoronskii — MD, PhD; i.v.gaivoronsky@mail.ru

Fredrik Boer - MD, PhD; fboer@lumc.nl

Pancras C.W.Hogendoorn - MD, PhD; p.c.w.hogendoorn@lumc.nl

\section{Appendix}

\section{Dutch and Russian students of the Leiden University, who played a significant role in the $17^{\text {th }}$ and $18^{\text {th }}$ century in the development of Medicine in Imperial Russia}

\begin{tabular}{|c|c|c|c|}
\hline Nr. & Year & Surname - First name & Title dissertation \\
\hline 1 & 1695 & Dohnell Joh.Just & Disputatio medica inauguralis de paralysi \\
\hline 2 & 1697 & Bidloo Nicolaas & Disputatio medica inauguralis de menstruorum suppressione \\
\hline 3 & 1699 & Brescius Zacharias & Disputatio physico-medica inauguralis de lumbricis \\
\hline 4 & 1712 & Burger Michael & Dissertatio medica inauguralis de morbis ossium \\
\hline 5 & 1712 & Gorter Johan de & Disputatio medica inauguralis de obstructione \\
\hline 6 & 1713 & Blumentrost Laurentius & Disputatio medica inauguralis de secretione animali \\
\hline 7 & 1717 & Hulst Arnoldus van der & Disputatio medica inauguralis, de circulatione sanguinis in foetu \\
\hline 8 & 1718 & Ardinois Franciscus & $\begin{array}{l}\text { Dissertatio medica inauguralis de fundamento totius medicinae } \\
\text { anatomica }\end{array}$ \\
\hline 9 & 1724 & Rieger Joh. Christiaan & Dissertatio medica inauguralis de anxietate \\
\hline 10 & 1728 & $\begin{array}{l}\text { Schreiber Joann } \\
\text { Friedrich }\end{array}$ & Meditationes philosophico-medicae de fletu \\
\hline 11 & 1729 & $\begin{array}{l}\text { Kaau-Boerhaave } \\
\text { Herman }\end{array}$ & Dissertation inauguralis de argento vivo \\
\hline 12 & 1732 & Condoidi Panajota & Dissertatio medica inauguralis de morbis aetatum \\
\hline 13 & 1738 & Barckhuysen Otto & $\begin{array}{l}\text { Dissertatio medica inauguralis sistens considerationem terrori } \\
\text { pathologico-therapeucitam }\end{array}$ \\
\hline 14 & 1738 & $\begin{array}{l}\text { Kaau-Boerhaave } \\
\text { Abraham }\end{array}$ & $\begin{array}{l}\text { Perspiratio dicta Hippocrati per universum corpus anatomice } \\
\text { illustrata }\end{array}$ \\
\hline
\end{tabular}




\begin{tabular}{|c|c|c|c|}
\hline Nr. & Year & Surname - First name & Title dissertation \\
\hline 15 & 1740 & $\begin{array}{l}\text { Gregory Joannes } \\
\text { Godofr }\end{array}$ & Dissertatio medica inauguralis de parte medicinae consultatoria \\
\hline 16 & 1743 & $\begin{array}{l}\text { Fischer Johannes } \\
\text { Benjamin }\end{array}$ & $\begin{array}{l}\text { Disseratio osteologica de modo, quo ossa se vicinis accommodant } \\
\text { partibus }\end{array}$ \\
\hline 17 & 1744 & Theyls Johannes & $\begin{array}{l}\text { Dissertatio medica inauguralis de sanguinis evacatione per } \\
\text { inferiora, quam haemorrhoidem vacant: ut causu fistulae an }\end{array}$ \\
\hline 18 & 1745 & Heister Lorenz et al. & $\begin{array}{l}\text { Fasciculus disseratonum medicarum quarum Ima De tunica } \\
\text { choroidea }\end{array}$ \\
\hline 19 & 1748 & Lups Johannes & Dissertatio physiologico medica inauguralis de irribilitate \\
\hline 20 & 1749 & $\begin{array}{l}\text { Kruse Carulos } \\
\text { Fridericus }\end{array}$ & Dissertatio medica inauguralis de causis acidi in primis viis \\
\hline 21 & 1749 & Sevasto Andreas & Dissertatio medica inauguralis de lithogenesi \\
\hline 22 & 1750 & Bacherat Henricus & Dissertatio medica inauguralis de morbis ligamentorum \\
\hline 23 & 1752 & Klanke Franciscus & Dissertatio medica inauguralis, de usu venarum \\
\hline 24 & 1753 & Staehlin Joann & $\begin{array}{l}\text { Dissertatio chirugico-medica inauguralis, sistens partum cum } \\
\text { haemorrhagia uteri conjunctum }\end{array}$ \\
\hline 25 & 1754 & Poletyka Joannes de & Dissertatio medica inauguralis, de morbis haereditariis \\
\hline 26 & 1756 & Rauschert Joachimus & Dissertatio chirurgico-medica inauguralis, de carie ossium \\
\hline 27 & 1757 & Jever Rudolphus & Specimen medicum de causis haemorrhagiarum \\
\hline 28 & 1758 & Scepin Constatinus & $\begin{array}{l}\text { Schediasma chemico-medicum inaugurale de acido vegetabili, } \\
\text { quod ... cum annotationibus botanicus }\end{array}$ \\
\hline 29 & 1760 & $\begin{array}{l}\text { Mautt Johannes } \\
\text { Fridericus }\end{array}$ & Dissertatio medica inauguralis de cortice Peruviano \\
\hline 30 & 1761 & $\begin{array}{l}\text { Melle Chritophoris } \\
\text { Andreas de }\end{array}$ & $\begin{array}{l}\text { Med. Doct. Dissertatio medica de vi vitali quoad medicinam et ex } \\
\text { illa morbi oriuntes }\end{array}$ \\
\hline 31 & 1764 & $\begin{array}{l}\text { Thorvath Joannes } \\
\text { Guilielmus }\end{array}$ & Dissertatio practico-medica inauguralis de lactis defectu \\
\hline 32 & 1764 & Zibelin Simeon & $\begin{array}{l}\text { Disseratio chemico-medica inauguralis, de saponibus medicis } \\
\text { nativis, ex triplici regno petitis, eorumque a chemicis differentia, } \\
\text { principiis, indole, ac usu in medicina }\end{array}$ \\
\hline 33 & 1765 & Fialkouski Stephanus & Dissertatio medica inauguralis de actione ventriculi in ingesta \\
\hline 34 & 1765 & Jagelski Cassianus & Dissertatio medico-practica inauguralis de passione hysterica \\
\hline 35 & 1765 & Kruten Matthias & Spec. med. Inaug. De manducatione \\
\hline 36 & 1765 & $\begin{array}{l}\text { Mitrofanov Sila } \\
\text { Mitrifanovic }\end{array}$ & Disp. Phys.-med. Inaug. De spontaneo aeris introitu in pulmonem \\
\hline 37 & 1765 & Pogoretski Petr & $\begin{array}{l}\text { Specimen chemicum inaugurale sistens aliqua de semimetallo } \\
\text { nickel, cui accedit examen medicum modi, quo vulgus expilare } \\
\text { ulcera solt }\end{array}$ \\
\hline
\end{tabular}




\begin{tabular}{|c|c|c|c|}
\hline Nr. & Year & Surname - First name & Title dissertation \\
\hline 38 & 1765 & Roschalyn Cosmas & Dissertatio medica inauguralis se scorbuto \\
\hline 39 & 1765 & Timkousky Josephus & Dissertatio medica inauguralis de peripneumonia notha \\
\hline 40 & 1765 & Tychorski Thomas & $\begin{array}{l}\text { Dissertatio medica inauguralis de vera sive proxima caussa } \\
\text { podagrae }\end{array}$ \\
\hline 41 & 1767 & $\begin{array}{l}\text { Knobloch Georgius } \\
\text { Ludovicus }\end{array}$ & $\begin{array}{l}\text { Dissertatio medico-practica inauguralis de entero mesocolocele } \\
\text { suffocata }\end{array}$ \\
\hline 42 & 1771 & à Skiada Mikhael & $\begin{array}{l}\text { Specimen physico-medicum inaugurale de solidid artis salutaris } \\
\text { fundamentis }\end{array}$ \\
\hline 43 & 1780 & Kurika Theodos & Theses med. inaug \\
\hline 44 & 1780 & Samoilowitz Daniil & $\begin{array}{l}\text { Dissertatio medico-chirurgico inauguralis sistens comparationem } \\
\text { inter sectionem symphyseos ossium pubis et sectionem caesaream }\end{array}$ \\
\hline 45 & 1781 & Politkovsky Theodorus & Dissertation inauguralis, de pyogenia seu formatione puris \\
\hline 46 & 1790 & Kolokolnikov Vasily & Theses med. inaug \\
\hline
\end{tabular}

